\title{
The effect of mitotane on viability, steroidogenesis and gene expression in NCI-H295R adrenocortical cells
}

\author{
TOMASZ P. LEHMANN, TOMASZ WRZESIŃSKI and PAWEŁ P. JAGODZIŃSKI
}

\begin{abstract}
Department of Biochemistry and Molecular Biology, Poznan University of Medical Sciences, Poznan 60-781, Poland
\end{abstract}
Received September 19, 2012; Accepted November 26, 2012

DOI: $10.3892 / \mathrm{mmr} .2012 .1244$

\begin{abstract}
Mitotane, also known as o,p'-DDD or (RS)-1-chloro-2-[2,2-dichloro-1-(4-chlorophenyl)-ethyl]-benzene, is an adrenal cortex-specific cytotoxic drug used in the therapy of adrenocortical carcinoma (ACC). The drug also inhibits steroidogenesis, however, the mechanisms of its anticancer and antisteroidogenic effects remain unknown. At present, data on the impact of mitotane on cell viability and the regulation of genes encoding proteins associated with steroids synthesis in the adrenal cortex, including cortisol and dehydroepiandrosterone sulfate (DHEAS), are limited and contradictory. In the present study, the effect of 24-h mitotane treatment on viability of the ACC cell line, NCI-H295R, was analyzed, identifying a decrease in cell viability and an increase in caspase- 3 and -7 activities. Mitotane treatment also led to decreased cortisol and DHEAS concentration in the culture media. Concomitantly, mitotane resulted in decreased mRNA levels of two cytochromes P450 (CYP11A1 and CYP17A1), mRNAs encoding proteins involved in the synthesis of cortisol and DHEAS. Mitotane did not affect mRNA levels of cyclin dependent kinase inhibitor 1A (encoding p21) and MYC (encoding cMyc). cMyc and p21 are key transcription factors associated with cell cycle regulation. However, mitotane inhibited expression of transforming growth factor $\beta 1$ gene, encoding a potent inhibitor of cell proliferation and steroidogenesis. PRKARIA, a protein kinase A regulatory subunit, is involved in the activation of steroidogenesis. PRKARIA mRNA levels were reduced following 24-h treatment with mitotane. Results indicate that mitotane markedly inhibited expression of genes involved in steroidogenesis, secretion of cortisol and DHEAS. Reduced expression of TGFB1 cannot account fully for the effect of mitotane on CYP11A1 and CYP17A1. We hypothesized that reduced viability of NCI-H295R cells in the presence of mitotane may be a result of apoptosis triggered by increased caspase- 3 and -7 activities. Since p21 and cMyc mRNA levels
\end{abstract}

Correspondence to: Dr Tomasz Lehmann, Department of Biochemistry and Molecular Biology, Poznan University of Medical Sciences, 6 Swiecickiego St., Poznan 60-781, Poland

E-mail: tlehmann@ump.edu.pl

Key words: adrenal, cancer, gene expression, o,p'-DDD were stable in the presence of mitotane, the mechanism by which caspase- 3 and -7 are induced remains unknown.

\section{Introduction}

Mitotane, also known as o,p'-DDD or (RS)-1-chloro-2-[2,2dichloro-1-(4-chlorophenyl)-ethyl]-benzene, was introduced 50 years ago and is currently the only FDA-approved drug for the treatment of adrenocortical carcinoma (ACC) $(1,2)$. Plasma mitotane concentration in patients with ACC reaches $20 \mathrm{mg} / \mathrm{l}$ (3). Plasma concentrations exceeding this are associated with a number of side effects of the digestive and central nervous systems (4). Mitotane therapy leads to a decrease in the secretion of steroid hormone and therefore supplementary glucocorticoid or mineralocorticoid therapy is recommended (5). Mitotane has been shown to increase patient survial in only $33 \%$ of cases (6) and studies have been performed to analyze the efficacy of combinations of etoposide, doxorubicin, cisplatin and mitotane or streptozocin and mitotane (7). A number of hypotheses have been put forward to explain this narrow window of mitotane efficiency. Concentration of mitotane appears to vary considerably between patients due to differences in transport from the digestive system to the blood stream and efficiency of liver detoxification (7). A mitotane concentration $<14 \mathrm{mg} / \mathrm{l}$ has no effect in the majority of patients, therefore, blood concentration is a limiting factor of mitotane efficiency (8).

Frequent chromosomal abnormalities in ACCs may affect the response of the adrenal gland to mitotane treatment. Malignant aberrations have been reported in loci 17p (TP53) and 11p15 (insulin-like growth factor-II) only $(9,10)$. Therefore, the identification of a suitable biomarker for the prediction of ACC response to mitotane remains unsuccessful. However, a biomarker to distinguish between adrenocortical adenoma and ACC has been found by genome and transcriptome screening $(9,10)$. At present, the determination of markers to predict the efficacy of mitotane therapy requires additional studies.

There are two general applications of mitotane. The first is for treatment of ACCs that cannot be surgically removed and the second is as an adjuvant treatment following adrenalectomy to prevent recurrence (7). A biomarker for prediction of mitotane response is required for ACCs that cannot be removed surgically as access to adrenal tissue is not possible. The ideal biomarker of mitotane response would measure 
a property of blood samples extracted from preoperative patients. ACC tumor tissues obtained following surgery may be diagnosed using a number of methods, including gene expression and genetic aberration assays in the cells cultured in vitro. Biomarkers must be extremely sensitive to a low dose of mitotane and measured easily in a cell extract or culture.

Mitotane lowers secretion of steroid hormones by targeting enzymes involved in the steroidogenic pathway, including $11 \beta$-hydroxylase [encoded by cytochrome P450 (CYP11) B1] and cytochrome $\mathrm{P} 450$ side chain cleavage (P450scc, encoded by $C Y P 11 A 1$ ) (5). Previously, mitotane and its derivatives were analyzed in the NCI-H295R human ACC cell line. Mitotane was reported to decrease cortisol and aldosterone secretion as well as 3 $\beta$-hydroxysteroid dehydrogenase/ $\delta 5-4$ isomerase type I (HSD3B1) mRNA levels (11). By contrast, inconsistent results were observed for the inhibitory effect of mitotane on the expression of steroidogenic genes, steroidogenic acute regulatory protein $(S t A R), C Y P 11 B 1, C Y P 17 A 1$ and $C Y P 11 B 2$ (gene-encoding aldosterone synthase) $(11,12)$.

Adrenocortical cells secrete mineralocorticoids (mainly aldosterone), glucocorticoids (mainly cortisol) and adrenal androgens [androstendione and dehydroepiandrosterone sulfate (DHEAS)] in the glomerulosa, fasciculata and reticularis zones of the adrenal gland, respectively. The main substrate of steroidogenesis is extracellular and intracellular cholesterol, which is transported to the external mitochondrial membrane. StAR transports cholesterol from the outer to the inner membrane of the mitochondria. The first mitochondrial step of steroid hormone synthesis is cleavage of cholesterol into pregnenolone by cholesterol desmolaze (P450scc, EC 1.14.15.6, encoded by $C Y P 11 A 1)$ (13). Cholesterol desmolaze, whose gene expression is regulated by adrenocorticotropic hormone (ACTH) via cAMP and the PKA pathway, limits synthesis of steroid hormones. The adrenal $17 \alpha$-hydroxylase/17,20-lyase microsomal enzyme system includes cytochrome $\mathrm{P} 450$ oxidoreductase (POR), cytochrome $\mathrm{b}_{5} \mathrm{~A}(\mathrm{CYB} 5 \mathrm{~A})$ and cytochrome $\mathrm{P} 450 \mathrm{c} 17$ (steroid $17 \alpha$-monooxygenase, encoded by $\mathrm{P} 450 \mathrm{c} 17$, EC 1.14.99.9, encoded by CYP17A1) $(14,15)$. CYP17A1 expression is stimulated by ACTH-triggered pathways (16).

In addition to the inhibition of steroidogenesis, mitotane acts as a cytotoxic drug $(12,17)$, hypothosized to be mediated by induction of apoptosis (18). However, the molecular mechanisms of mitotane-mediated regulation of steroidogenesis and adrenocortical cell viability remain unclear. Previous studies on the effect of mitotane on the expression of genes encoding proteins involved in steroid hormone production are contradictory $(11,12)$. In addition, cell viability results differ between these studies. To the best of our knowledge, no studies have analyzed the expression of genes associated with cell cycle regulation, including cyclin dependent kinase inhibitor 1A, (encoding p21;CDKN1A) and MYC (encoding cMyc), as well as genes involved in important regulatory pathways in adrenocortical cells, including transforming growth factor $\beta 1$ (TGF $\beta 1$ ) and the PKA regulatory subunit, PRKARlA, following mitotane treatment. In the present study, whether mitotane regulates the expression of key genes involved in steroidogenesis, $C Y P 11 A 1$ and $C Y P 17 A 1$, as well as important regulators of the cell cycle, TGFB1, PRKARIA, CDKN1A and $M Y C$ was investigated. Since the human adrenocortical cell line NCI-H295R originates from human ACC, this cell line was used to investigate mitotane effects on cancerous adrenocortical cells. These genes were selected following analysis of microarray data from publically available resources (19) and from previous studies describing genetic aberrations in ACC. CYP11A1, CYP17A1, TGFB1, PRKAR1A and MYC are located in loci in which aberrations have been previously detected in ACC tumors (20-22). CDKN1A is not located in a locus known to be aberrated in ACC tumors. The present study is likely to aid selection of a biomarker for distinguishing between mitotane-sensitive and -insensitive ACCs.

\section{Materials and methods}

Materials. The human adrenocortical NCI-H295R cell line was obtained from Dr W. Rainey (Dallas, TX, USA). Plasmids containing the CYP11A1 promoter fragment (605 bp) were obtained from Dr W. Miller (San Francisco, CA, USA) (23) and vectors containing the CYP17A1 promoter fragments were obtained from Dr M. Sewer (Nashville, TN, USA) (24). Mitotane was purchased from Sigma-Aldrich (St. Louis, MO, USA).

Cell culture. NCI-H295R cells were cultured at $37^{\circ} \mathrm{C}$ and $5 \% \mathrm{CO}_{2} / 95 \%$ air in DMEM/F-12 (1:1 v/v) supplemented with $1.25 \%$ L-glutamine, $2.5 \%$ NuSerum (BD Biosciences, Franklin Lakes, NJ, USA), 1\% ITS plus (BD Biosciences) and antibiotic antimycotic solution (Sigma-Aldrich). Confluent cells were incubated for $24 \mathrm{~h}$ in DMEM/F-12 prior to treatment with mitotane.

Hormonal test. Following 24-h incubation with mitotane, concentrations of cortisol and DHEAS in the media were measured using an electrochemiluminescence immunoassay (Cobas 6000, Roche Diagnostics, Burgess Hill, UK). Hormone concentrations were normalized against total protein in the same well, determined by the Bradford colorimetric assay (Bio-Rad, Hercules, CA, USA).

Cell viability and caspase- 3 and -7 activities. To analyze cell viability, the Cell Growth Determination kit, 3-(4,5-dimethylthiazol-2-yl)-2,5-diphenyltetrazolium bromide (MTT; Sigma-Aldrich), was used. Following 24-h mitotane incubation, cells (in 24-well plates) were incubated in DMEM/F-12 and $10 \%$ MTT $(0.5 \mathrm{mg} / \mathrm{ml})$ for $4 \mathrm{~h}$. Media were removed and a solvent was added (0.1 M hydrochloric acid in isopropanol). Following gentle mixing, absorbance was measured at $630 \mathrm{~nm}$ and the background absorbance was measured at $405 \mathrm{~nm}$ using a Stat-Fax 2100 spectrophotometer (Awareness Technology, Inc., Palm City, FL, USA).

Caspase-3 and -7 activities were analyzed with the Caspase-Glo 3/7 assay kit (Promega, Madison, WI, USA). After 24-h stimulation, the Caspase-Glo 3/7 reagent was added to the cell culture medium in a 96-well plate in a 1:4 ratio and incubated for $1 \mathrm{~h}$. Luminescence was measured using a TD-20/20 luminometer (Turner BioSystems, Sunnyvale, CA, USA).

Gene expression. Following incubation, total RNA was extracted from the cultured cells using TRItidy G, according to the manufacturer's instructions (Applichem, Darmstadt, Germany). Extracted total RNA $(1 \mu \mathrm{g})$ was reverse-transcribed 
Table I. Oligonucleotide sequences used in quantitative PCR.

\begin{tabular}{|c|c|c|c|}
\hline Gene name & Oligonucleotide sequence & $\begin{array}{l}\text { Amplicon } \\
\text { length (bp) }\end{array}$ & $\begin{array}{c}\text { ENSEMBL } \\
\text { accession number }\end{array}$ \\
\hline$M Y C$ & $\begin{array}{l}\text { 5'-CСТАСССТCTCAACGAC-3' } \\
\text { 5'-ATCTTCTTGTTCCTCCTCAG-3' }\end{array}$ & 188 & ENSG00000136997 \\
\hline CYP11A1 & $\begin{array}{l}\text { 5'-TGTTGAAGAAGTCGGCAG-3' } \\
\text { 5'-TAGTGATGGACTCAAAGG-3' }\end{array}$ & 216 & ENST00000268053 \\
\hline CYP17A1 & $\begin{array}{l}\text { 5'-TGGCCCCATCTATTCTGTTC-3' } \\
\text { 5'-CTTCTCCAGCTTCTGATCGC-3' }\end{array}$ & 454 & ENSG00000148795 \\
\hline$H M B S$ & $\begin{array}{l}\text { 5'-GCCAAGGACCAGGACATC-3' } \\
\text { 5'-TCAGGTACAGTTGCCCATC-3' }\end{array}$ & 160 & ENST00000442944 \\
\hline MRPL19 & $\begin{array}{l}\text { 5'-ACTTTATAATCCTCGGGTC-3' } \\
\text { 5'-ACTTTCAGCTCATTAACAG-3' }\end{array}$ & 171 & ENST00000393909 \\
\hline$C D K N 1 A$ & $\begin{array}{l}\text { 5'-CCAGCATGACAGATTTCTAC-3' } \\
\text { 5'-CACACAAACTGAGACTAAGG-3' }\end{array}$ & 148 & ENST00000244741 \\
\hline PRKARIA & $\begin{array}{l}\text { 5'-TCCTCATGGGAAGCACAC-3' } \\
\text { 5'-AGCTGACCCCTCTAAAATAA-3' }\end{array}$ & 200 & ENST00000358598 \\
\hline TGFBI & $\begin{array}{l}\text { 5'-GAAACCCACAACGAAATC-3' } \\
\text { 5'-AATTTCCCCTCCACGGCT-3' }\end{array}$ & 300 & ENST00000358598 \\
\hline
\end{tabular}

using the Superscript Reverse Transcriptase kit (Life Technologies, Carlsbad, CA, USA). Oligo(dT)15-primed cDNAs were amplified by quantitative PCR (qPCR) using the primers listed in Table I and the LightCycler FastStart DNA Master SYBR-Green I kit (Roche Diagnostics). Crossing points were calculated automatically based on a second derivative algorithm and the results were analyzed by the relative expression method. mRNA levels of hydroxymethylbilane synthase $(H M B S)$ and 39S ribosomal protein L19, mitochondrial (MRPL19) were determined and used as reference genes.

Transient transfection and luciferase assay. Following culture, cells were cotransfected, using Lipofectamine PLUS (Invitrogen Life Technologies, Carlsbad, CA, USA), with pGL3 plasmid containing $-57,-300$ and $-700 \mathrm{bp}$ fragments of the $C Y P 17 A 1$ promoter or a -605 bp fragment of the $C Y P 11 A 1$ promoter $(0.5 \mu \mathrm{g})$ fused to Photinus luciferase and the pRL-TK plasmid $(0.05 \mu \mathrm{g})$ containing the Renilla luciferase gene, the latter of which was used as a control of transfection efficiency.

Following transfection, cells were incubated for $24 \mathrm{~h}$ with mitotane, harvested and lysed with passive lysis buffer. Luciferase activities in the cell lysates were determined using the Dual Luciferase System (Promega) and TD-20/20 luminometer (Turner BioSystems).

Statistical analysis. Results (mean \pm SEM) from at least three independent experiments were expressed as the fold change from a control value. One-way analysis of variance was also used to evaluate the results obtained by qPCR. Post-hoc comparisons were performed with the Student-Newman-Keuls test. $\mathrm{P}<0.05$ was considered to indicate a statistically significant difference.

\section{Results}

The effect of mitotane on NCI-H295R cell viability and activities of caspase-3 and -7. Mitotane is a potent inhibitor of adrenocortical cancer cell growth. NCI-H295R adrenocortical cells were incubated with various concentrations of mitotane for $24 \mathrm{~h}$. Concentrations between 0 and $2 \mathrm{mg} / \mathrm{l}(6.25 \mu \mathrm{M})$ did not affect NCI-H295R viability (Fig. 1A). However, $20 \mathrm{mg} / 1(62.5 \mu \mathrm{M})$ mitotane caused a $20 \%$ decrease in cell viability (Fig. 1A). Since blood concentration of mitotane has been identified to be $\sim 14 \mathrm{mg} / 1(43.75 \mu \mathrm{M})$ in ACC patients and is detected for considerably longer than $24 \mathrm{~h}$ in the blood, mitotane may markedly decrease viability of ACC cells.

Mitotane concentrations between $0.2(0.6 \mu \mathrm{M})$ and $16 \mathrm{mg} / \mathrm{l}$ $(50 \mu \mathrm{M})$ did not cause a detectable change in activities of caspase-3 or -7 (Fig. 1B). Mitotane doses between $20(62.5 \mu \mathrm{M})$ and $32 \mathrm{mg} / \mathrm{l}(100 \mu \mathrm{M})$ led to an increase in caspase- 3 and -7 activities by up to a 2.0- and 2.5-fold, respectively. These data indicate that inhibition of NCI-H295R cell viability by mitotane may be caused by apoptosis.

Regulation of steroid hormone secretion by mitotane in NCI-H295R cells. Low doses of mitotane, between $2(6.25 \mu \mathrm{M})$ and $4 \mathrm{mg} / \mathrm{l}(12.5 \mu \mathrm{M})$, were sufficient to cause an $80 \%$ decrease of cortisol and DHEAS secretion (Fig. 2). Higher doses of mitotane between $8(25 \mu \mathrm{M})$ and $32 \mathrm{mg} / \mathrm{l}(100 \mu \mathrm{M})$ did not lead 
A

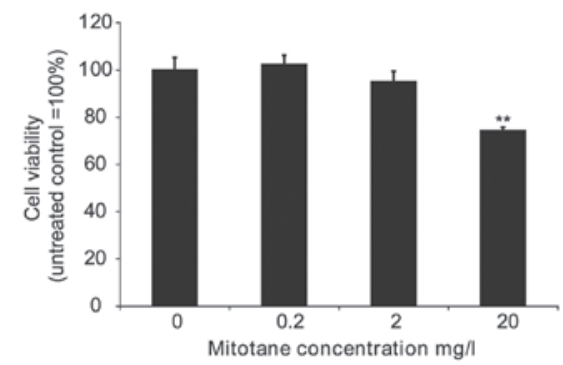

B

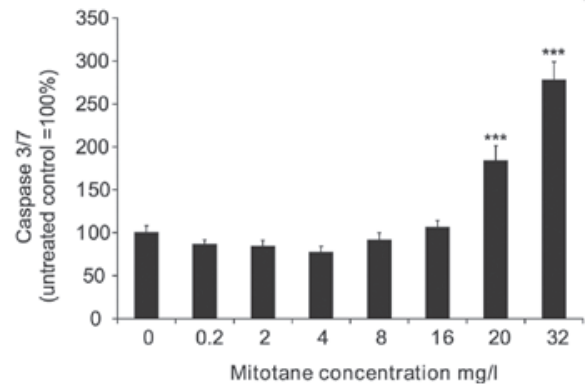

Figure 1. NCI-H295R cell viability and caspase- 3 and -7 activity in cells treated with various doses of mitotane. (A) NCI-H295R cells were incubated with $0.2,2.0$ and $20 \mathrm{mg} / 1(0.625,6.25$ and $62.5 \mu \mathrm{M})$ mitotane for $24 \mathrm{~h}$ followed by incubation with MTT for $4 \mathrm{~h}$. (B) NCI-H295R cells were incubated with $0.2,2.0,4.0,8.0,16,20$ and $32 \mathrm{mg} / 1(0.625,6.25,12.5,25,50,62.5$ and $100 \mu \mathrm{M}$ ) mitotane to measure caspase- 3 and -7 activity. Following $24 \mathrm{~h}$, cells were incubated with a caspase detection buffer and the luminescent signal was measured following $1 \mathrm{~h}$. Data are presented as the percentage of the control $(100 \%)$. Each experiment was repeated four times, error bars represent \pm SEM. ${ }^{* *} \mathrm{P}<0.01,{ }^{* * * *} \mathrm{P}<0.001$.

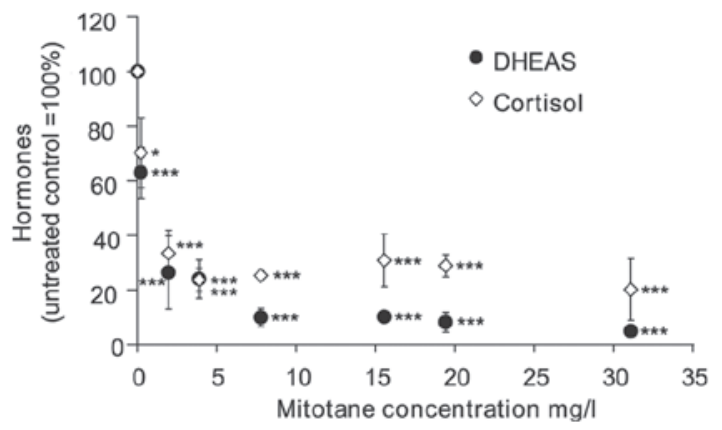

Figure 2. Cortisol and DHEAS secretion in NCI-H295R cells treated with various doses of mitotane. NCI-H295R cells were incubated with $0.2,2.0$, $4.0,8.0,16,20$ and $32 \mathrm{mg} / 1(0.625,6.25,12.5,25,50,62.5$ and $100 \mu \mathrm{M})$ mitotane. Following $24 \mathrm{~h}$, cortisol and DHEAS levels were measured by ECLIA. Data are presented as the percentage of the control (100\%). Each experiment was repeated four times, error bars represent \pm SEM. $P<0.05$, ${ }^{* * *} \mathrm{P}<0.001$. ECLIA, electrochemiluminescence immunoassay. DHEAS, dehydroepiandrosterone sulfate.

to greater inhibition of cortisol secretion. However, DHEAS secretion was diminished by 90 and $95 \%$ in cells treated with $8(25 \mu \mathrm{M})$ and $32 \mathrm{mg} / \mathrm{l}(100 \mu \mathrm{M})$ mitotane, respectively.

The mean concentration of cortisol in the media was $18.5 \mathrm{nM}$ for control and $2.55 \mathrm{nM}$ in $20 \mathrm{mg} / 1(62.5 \mu \mathrm{M})$ mitotane following 24-h incubation. Cortisol concentrations in the media were calculated as $\mathrm{pmol} / \mu \mathrm{g}$ protein. Control was 0.45 $\mathrm{pmol} / \mu \mathrm{g}$ and $20 \mathrm{mg} / \mathrm{l}$ mitotane was $0.13 \mathrm{pmol} / \mu \mathrm{g}$ following 24-h incubation. Data shown in Fig. 2 represent $\mathrm{pmol} / \mu \mathrm{g}$ values transformed into percentage of control (100\%).

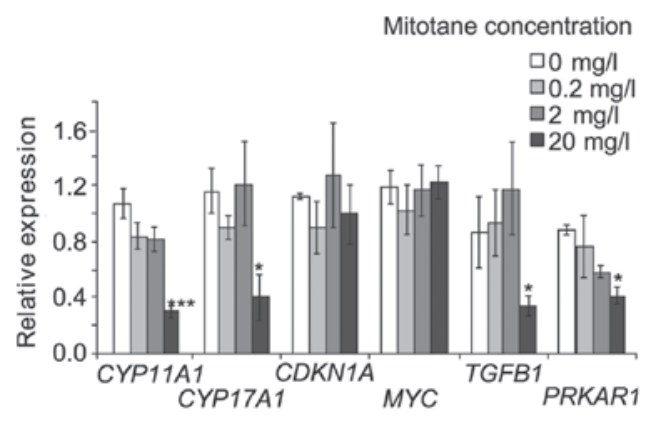

Figure 3. mRNA levels of CYP11A1, CYP17A1, CDKN1A, MYC, TGFB1 and PRKAR1A in NCI-H295R cells treated with $0.2,2.0$ and $20 \mathrm{mg} / \mathrm{l}(0.625,6.25$ and $62.5 \mu \mathrm{M})$ mitotane for $24 \mathrm{~h}$. MRPL19 and HMBS genes were used as internal references. mRNA levels were measured by qPCR. Data were analyzed by the relative expression method and each experiment was repeated four times. Error bars represent $\pm \mathrm{SEM}$. ${ }^{*} \mathrm{P}<0.05,{ }^{* *} \mathrm{P}<0.01,{ }^{* * *} \mathrm{P}<0.001 . C Y P$, cytochrome $\mathrm{P} 450 ;$ PRKAR1A, protein kinase A regulatory subunit; TGFB1, transforming growth factor $\beta$.

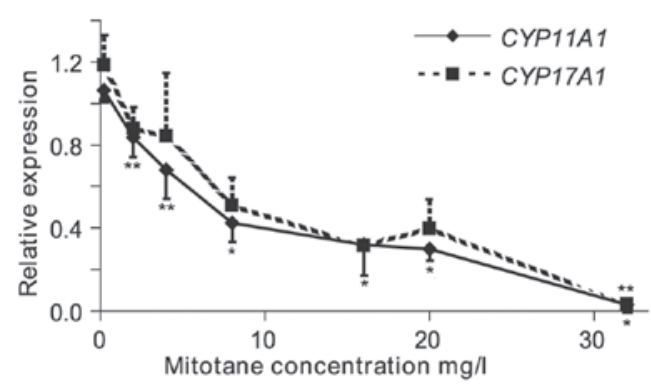

Figure 4. mRNA levels of CYP11A1 and CYP17A1 in NCI-H295R cells treated with $0.2,2.0,4.0,8.0,16,20$ and $32 \mathrm{mg} / 1(0.625,6.25,12.5,25,50$, 62.5 and $100 \mu \mathrm{M}$ ) mitotane for $24 \mathrm{~h}$. mRNA levels were measured by qPCR. $M R P L 19$ and HMBS mRNA levels were used as internal references. Data were analyzed by the relative expression method and each experiment was repeated at least three times. Error bars represent \pm SEM, only down bars corresponding to -SEM are included for CYP11A1 and only up bars corresponding to $+\mathrm{SEM}$ are included for CYP17A1. ${ }^{*} \mathrm{P}<0.001,{ }^{* *} \mathrm{P}<0.05$.

The mean concentration of DHEAS in the media was 440 and $130 \mathrm{nM}$ for control and $20 \mathrm{mg} / 1(62.5 \mu \mathrm{M})$ mitotane, respectively. Following calculation of DHEAS concentration in the media as pmol $/ \mu \mathrm{g}$ protein, control was $6.3 \mathrm{pmol} / \mu \mathrm{g}$ and $20 \mathrm{mg} / \mathrm{l}(62.5 \mu \mathrm{M})$ mitotane was $0.47 \mathrm{pmol} / \mu \mathrm{g}$.

The effect of mitotane on gene expression in NCI-H295R cells. To verify which genes are regulated in NCI-H295R cells, mRNA levels of CYP11A1, CYP17A1, CDKN1A, MYC, TGFB1 and PRKAR1A were determined in NCI-H295R cells treated with 0.2, 2.0 and $20 \mathrm{mg} / \mathrm{l}$ mitotane for $24 \mathrm{~h}$ (Fig. 3). mRNA encoding enzymatic proteins involved in steroidogenesis, CYP11A1 and CYP17A1, were decreased by 72 and $65 \%$, respectively, in cells treated with $20 \mathrm{mg} / 1$ mitotane. CDKN1A and $M Y C$ mRNA levels were not affected by mitotane. TGFBI and PRKARIA mRNA levels were reduced by 65 and 57\%, respectively, by $20 \mathrm{mg} / \mathrm{l}(62.5 \mu \mathrm{M})$ mitotane.

In addition, mRNA expression levels of genes encoding enzymes involved in catalyzing limiting steps of steroidogenesis were analyzed to determine the mechanism of mitotane inhibition of steroidogenesis. Incubation of NCI-H295R cells 


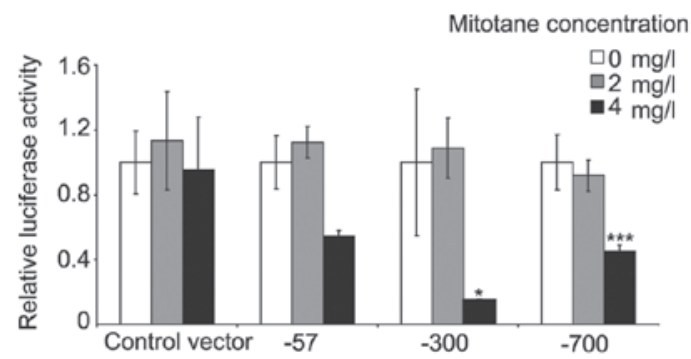

Figure 5. CYP17A1 promoter fragment activity in NCI-H295R cells treated with mitotane. NCI-H295R cells were transfected with luciferase reporter plasmids containing CYP17A1 promoter fragments of 57, 300 and $700 \mathrm{bp}$ and treated subsequently with 2.0 and $4.0 \mathrm{mg} / 1(6.25$ and $12.5 \mu \mathrm{M})$ mitotane for $24 \mathrm{~h}$. Renilla luciferase was used as internal reference. Each experiment was repeated at least three times and error bars represent \pm SEM. ${ }^{* * *} \mathrm{P}<0.001$, ${ }^{*} \mathrm{P}<0.05$. CYP, cytochrome $\mathrm{P} 450$.

with between 0.2 and $32 \mathrm{mg} / 1$ mitotane reduced $C Y P 11 \mathrm{Al}$ and CYP17A1 mRNA levels (Fig. 4).

Mitotane inhibits CYP17A1 promoter activity. To determine whether mitotane targets $C Y P 17 A 1$ expression at the transcriptional or post-transcriptional level, NCI-H295R cells were transfected with plasmids containing 3 (57, 300 or $700 \mathrm{bp})$ upstream fragments of the $C Y P 17 A 1$ promoter fused to the luciferase gene. The fragments of $C Y P 17 A 1$ were inhibited by $4 \mathrm{mg} / \mathrm{l}$ mitotane following $24-\mathrm{h}$ incubation. No effect was observed at $2 \mathrm{mg} / \mathrm{l}$ mitotane. The transfection system was compromised by $>4 \mathrm{mg} / \mathrm{l}$ mitotane and the luciferase activity signal was not detectable. Significant inhibition of the 300 and 700 bp fragments by mitotane was observed. These fragments contain cAMP response elements indicating that $C Y P 17 A 1$ promoter regulation by cAMP and mitotane may be coupled (Fig. 5).

\section{Discussion}

Mitotane, an anti-ACC drug has been known for a number of years to reduce adrenocortical steroidogenesis and cell growth (17). Previously, mitotane and its derivatives were revealed to decrease the viability of Y1 and NCI-H295R cells $(11,25)$ as well as steroidogenesis in NCI-H295R cells $(11,12,25)$. The present study is consistent with results of Lin et al demonstrating that mitotane decreased expression of CYP11A1 and CYP17A1 genes in NCI-H295R cells. In addition, current results reveal that activity of the $C Y P 17 A 1$ promoter was diminished by mitotane (12). For the first time decreased viability of NCI-H295R cells was accompanied by increased caspase-3 and -7 activities. Expression of $M Y C$ and $C D K N 1 A$, two important genes involved in cell cycle regulation, was unchanged. By contrast, TGFBI and PRKARIA mRNA levels were diminished.

Previously, Asp et al observed decreased viability of NCI-H295R cells in the presence of mitotane (11). However, a $90 \%$ reduction in cell viability was noted in NCI-H295R cells treated for $72 \mathrm{~h}$ with $6.4 \mathrm{mg} / \mathrm{l}(20 \mu \mathrm{M})$ mitotane compared with $20 \%$ in the present study. Lin et al did not observe a decrease in cell viability with $12.8 \mathrm{mg} / 1(40 \mu \mathrm{M})$ mitotane (12). The highest concentration of mitotane used in the current study was
$20 \mathrm{mg} / \mathrm{l}(62.5 \mu \mathrm{M})$, which was found to decrease cell viability. This concentration is the highest level of mitotane achieved in the plasma of patients treated against ACC. These inconsistencies in results between studies may be caused by variations in cell culture conditions or genotype variants of NCI-H295R cell lines originating from ACC. At present these results make it difficult to predict the effect of mitotane in vivo. However, genetic variability in NCI-H295R cells may be considered to represent in vivo conditions where genetic diversity in ACCs result in variable outcomes of mitotane treatment in $\mathrm{ACC}$ patients (2).

Reduced cell survival following mitotane treatment may be caused by decreased cell viability or the number of cell divisions as well as cell cycle arrest or apoptosis. Similar to mitotane, 1,1-dichloro-2,2 bis ( $\mathrm{p}$-chlorophenyl) ethylene (DDE) is a DDT derivative and has been demonstrated to induce apoptosis in rat Sertoli cells. In addition, DDE has been observed to increase caspase-3 mRNA levels (26). However, a previous study in MCF-7 estrogen responsive cells, demonstrated that estrogenic organochlorine pesticides, including o,p'-DDT, mimic the endogenous estrogen, $17 \beta$-estradiol and suppress apoptosis (27). To determine the mechanism by which mitotane reduces cell number, caspase- 3 and -7 activities were determined. Caspase- 3 and -7 are executioner caspases present in the cytosol as inactive zymogen dimers which are activated by initiator caspases- 8 and -9 (28). Lakhani et al previously reported that caspase- 3 and -7 regulate mitochondrial events in the apoptotic pathway (29). Caspase-3 and -7 exhibit analogous properties and demonstrate similar substrate specificities $(30,31)$. It has been hypothesized that caspase-3 activation does not necessarily lead to terminal apoptosis. DNA electrophoresis following 24-h mitotane treatment was performed (data not shown and a typical apoptotic ladder of DNA bands was not observed, inconsistent with the apoptotic effect of mitotane) $(32,33)$. Further studies to determine whether mitotane induces programmed cell death or necrosis must be performed.

TGF $\beta 1$ regulates adrenal development, inhibits adrenal steroid production and decreases cell proliferation, therefore, in the present study TGFBl gene expression was investigated $(34,35)$. The growth factor alters the cell cycle, activates caspase- 3 and induces apoptosis in adrenocortical cells via small mothers against decapentaplegic (SMAD) proteins (36). Decreased expression of TGFBI and concomitant stable expression of $C D K N 1 A$ were observed as well as increased caspase- 3 activity. Therefore, TGF $\beta 1$ was not considered to be a key factor in the mechanism of mitotane and the drug was hypothesized to trigger caspase-3 activity independently of the TGF $\beta 1 /$ SMAD/p21 pathway. Mitotane was observed to have similar effects in NCI-H295R as aspirin in human umbilical vein endothelial cells, suppressing TGF $\beta 1$ without altering expression of CDKN1A (37).

To determine whether decreased viability in NCI-H295R cell was mediated by an increase in execution caspases, a mediator of the mitotane effect, other than TGF $\beta 1$, which is involved in cell cycle regulation was investigated. $M Y C$ and $C D K N 1 A$ were hypothesized to be involved in this process. cMyc is an coordinator of cell proliferation and apoptosis, repressing specific survival pathways that regulate caspases. This process may be the mechanism by which cMyc promotes 
death receptor-induced apoptosis (38). cMyc affects a number of cell cycle regulators inducing caspase-dependent and -independent apoptosis (39). MYC expression is inhibited by TGF $\beta 1$ which triggers apoptosis in NCI-H295R cells (36). $M Y C$ mRNA expression levels were unchanged by mitotane, therefore we concluded that cMyc is not involved in mitotane dependent apoptosis in NCI-H295R cells or the decrease of viability is not a result of apoptosis. A previous study reported that p,p'-DDE may induce testicular apoptosis in rats through mitochondrial pathways, releasing cytochrome $\mathrm{c}$ and additional proapoptotic factors to activate caspase- 3 and -7 , which later promote cell death by directly processing and activating caspase-8 (26).

The cyclin-dependent kinase inhibitor, p21, is activated by p53-dependent and -independent mechanisms following stress, leading to cell cycle arrest and under specific conditions, induction of apoptosis (40). CDKNIA gene expression was analyzed to determine mitotane-induced cytotoxicity. Expression of $C D K N 1 A$ was not affected by mitotane. In general, CDKN1A expression is upregulated by apoptosis stimulating drugs, however, there are exceptions, such as sodium butyrate, an inhibitor of histone deacetylases (41). Sodium butyrate treatment increases caspase- 3 expression in human gastric cancer cells, however, the expression of TP53 and CDKN1A is unchanged (41).

Alterations in the expression of CDKN1A is not the only mechanism by which $\mathrm{p} 21$ activity is regulated. Phosphorylation of $\mathrm{p} 21$ by PKA leads to the formation of procaspase-3/p21 complexes rendering human hepatoma HepG2 cells resistant to Fas-mediated apoptosis (42). In the presence of mitotane, a decreased expression of PRKARIA was observed. Therefore, we hypothesized that a low expression of PRKARIA enables the free catalytic subunit of PKA to phosphorylate p21, blocking subsequent procaspase-3 cleavage. Inconsistent with this hypothesis, caspase- 3 activity in the current study was increased, indicating that although inactivation of procaspase- 3 by phosphorylated p21 blocked apoptosis in HepG2 cells, this mechanism does not occur in NCI-H295R cells. If the pathway is presumed to be active and catalytic subunit of PKA phosphorylates p21, the gradual decrease of ATP production by damaged mitochondria following treatment with mitotane may be responsible for the rupture of the procaspase-3/p21 complex. Mitochondrial damage begins with mitochondrial outer membrane permeabilization leading to the release of cytochrome $\mathrm{c}$, activation of caspase- 3 and -7 and then loss of transmembrane potential and collapse of ATP synthesis. These mitochondrial events may contribute to the failure of steroidogenesis (43).

A gradual decrease of cortisol and DHEAS in NCI-H295R cells following mitotane treatment was observed. Asp et al previously identified a comparable effect on cortisol secretion in NCI-H295R cells (11). Cortisol secretion was maximally inhibited by $4 \mathrm{mg} / \mathrm{l}$ mitotane and DHEAS was maximally inhibited by $8 \mathrm{mg} / \mathrm{l}$ mitotane. Since these low doses of mitotane decreased cortisol secretion, we hypothesized that steroid hormone production is interrupted by additional mechanisms to mitochondria damage. o,p'-DDT derivatives may partially mimic the activity of endogenous estrogen in MCF-7 cells (44). In NCI-H295R cells, estradiol alone increases production of DHEAS. By contrast, non-steroidal synthetic estrogen dieth- ylstilbestrol does not stimulate DHEAS production. Estradiol and diethylstilbestrol inhibited the NCI-H295R production of cortisol (45). The antisteroidogenic effect of mitotane on NCI-H295R is different to the effect of estrogen on these cells, therefore the anticancer drug and sex steroid were hypothesized to function via different pathways. Activin, a member of the TGF 11 family, inhibits steroidogenesis in NCI-H295R cells decreasing the secretion of cortisol and DHEAS as well as promoting apoptosis, however, this non-selective effect, similar to mitotane, is mediated by SMAD proteins (46).

NCI-H295R cells may be a suitable model for identification of a biomarker of mitotane efficacy. Collection and selection of various mitotane- and non-resistant strains of NCI-H295R cells for genome and transcriptome analysis of sensitive and non-sensitive cells must be performed in further studies to identify a biomarker.

In the present study, a mitotane-mediated decrease in the expression of key steroidogenic genes, CYP11A1 and CYP17Al, was detected. The effect of mitotane on CYPIIAl and CYP17Al expression levels was analyzed using a wider range of mitotane concentrations between 0.2 and $32 \mathrm{mg} / 1$, including $20 \mathrm{mg} / 1$, the maximal concentration of mitotane detected in patients treated for ACC. CYP11A1 and CYP17A1 are involved in cortisol and DHEAS synthesis. The proteins encoded by these genes are P450 cytochromes which function in the mitochondria and endoplasmic reticulum of adrenocortical cells. CYP11A1 and CYP17A1 mRNA levels gradually declined as the concentration of mitotane increased. By contrast, a stimulatory effect on CYP17A1 expression was previously observed by Asp et al in NCI-H295R cells treated with $1.6 \mathrm{mg} / \mathrm{l}$ mitotane (11). However, the authors did not report effects of higher concentrations of the drug. More recently, Lin et al reported results on mitotane treatment on CYP11A1 and CYP17A1 mRNA levels, consistent with the current study (12).

In this study, analysis of CYP11A1 promoter fragments indicated that CYP11Al is not regulated by mitotane at the transcriptional level (data not shown). By contrast, the promoter activity of CYP17A1 is markedly inhibited by mitotane. Mitotane inhibited the activity of the -300 bp CYP17Al promoter fragment, comprising a cAMP response element, indicating that activation by cAMP and inhibition by mitotane may be associated with common mechanisms (24).

The impairment of cortisol and DHEAS secretion by mitotane may be explained by reduced CYP17A1 and CYP11Al gene expression in NCI-H295R cells treated with the drug. In addition, the toxic effect of mitotane on mitochondria may also explain abnormalities in steroid synthesis. Mitochondria may also be involved in reduced cell viability promoted by mitotane. Increased caspase- 3 and -7 activities indicate that the reduced number of cells following mitotane treatment may be caused by apoptosis. Further investigations are required to explain the mechanism behind the effects of mitotane on cell viability, since the drug did not affect cMyc or p21, two key cell cycle regulators and an apoptotic DNA ladder was not observed. CYP11A1, CYP17A1, TGFB1 and PRKARIA were hypothesized to be candidates for biomarkers of the mitotane effect since mRNA expression of these genes were altered by treatment with mitotane. In addition, caspase or transfection analysis of the CYP17A1 promoter must be performed. Therefore, to analyze these biomarkers, patient cell culture 
must be performed and treated with mitotane for subsequent gene expression analysis and caspase response assays. Epigenome, genome aberration and transcriptome analysis must also be performed.

\section{Acknowledgements}

The authors thank Beata Raczak and Bogumiła Ratajczak for help during preparation of the current study. This study was partially supported by grants from the Polish Ministry of Science and Higher Education (NN 403 598538) and the Poznan University of Medical Sciences (no. 501-01-1124182-07635.)

\section{References}

1. Hahner S and Fassnacht M: Mitotane for adrenocortical carcinoma treatment. Curr Opin Investig Drugs 6: 386-394, 2005

2. Huang $\mathrm{H}$ and Fojo T: Adjuvant mitotane for adrenocortical cancer - a recurring controversy. J Clin Endocrinol Metab 93: 3730-3732, 2008.

3. Hermsen IG, Fassnacht M, Terzolo M, Houterman S, den Hartigh J, Leboulleux S, Daffara F, Berruti A, Chadarevian R, Schlumberger M, Allolio B, Haak HR and Baudin E: Plasma concentrations of o,p'DDD, o,p'DDA and o,p'DDE as predictors of tumor response to mitotane in adrenocortical carcinoma: results of a retrospective ENS@T multicenter study. J Clin Endocrinol Metab 96: 1844-1851, 2011.

4. Allolio B and Fassnacht M: Clinical review: Adrenocortical carcinoma: clinical update. J Clin Endocrinol Metab 91: 2027-2037, 2006.

5. Libe R, Fratticci A and Bertherat J: Adrenocortical cancer: pathophysiology and clinical management. Endocr Relat Cancer 14: 13-28, 2007.

6. Kirschner LS: Emerging treatment strategies for adrenocortical carcinoma: a new hope. J Clin Endocrinol Metab 91: 14-21, 2006.

7. Zini L, Porpiglia F and Fassnacht M: Contemporary management of adrenocortical carcinoma. Eur Urol 60: 1055-1065, 2011

8. Haak HR, Hermans J, van de Velde CJ, Lentjes EG, Goslings BM, Fleuren GJ and Krans HM: Optimal treatment of adrenocortical carcinoma with mitotane: results in a consecutive series of 96 patients. Br J Cancer 69: 947-951, 1994.

9. Gicquel C, Bertagna X, Gaston V, Coste J, Louvel A, Baudin E, Bertherat J, Chapuis Y, Duclos JM, Schlumberger M, Plouin PF, Luton JP and Le Bouc Y: Molecular markers and long-term recurrences in a large cohort of patients with sporadic adrenocortical tumors. Cancer Res 61: 6762-6767, 2001.

10. Ragazzon B, Libe R, Gaujoux S, Assie G, Fratticci A, Launay P, Clauser E, Bertagna X, Tissier F, de Reynies A and Bertherat J: Transcriptome analysis reveals that p53 and \{beta\}-catenin alterations occur in a group of aggressive adrenocortical cancers. Cancer Res 70: 8276-8281, 2010.

11. Asp V, Ulleras E, Lindstrom V, Bergstrom U, Oskarsson A and Brandt I: Biphasic hormonal responses to the adrenocorticolytic DDT metabolite 3-methylsulfonyl-DDE in human cells. Toxicol Appl Pharmacol 242: 281-289, 2010.

12. Lin CW, Chang YH and Pu HF: Mitotane exhibits dual effects on steroidogenic enzymes gene transcription under basal and cAMP-stimulating microenvironments in NCI-H295 cells. Toxicology 298: 14-23, 2012.

13. Gilep AA, Sushko TA and Usanov SA: At the crossroads of steroid hormone biosynthesis: the role, substrate specificity and evolutionary development of CYP17. Biochim Biophys Acta 1814: 200-209, 2011

14. Chung BC, Picado-Leonard J, Haniu M, Bienkowski M, Hall PF Shively JE and Miller WL: Cytochrome P450c17 (steroid 17 alpha-hydroxylase/17,20 lyase): cloning of human adrenal and testis cDNAs indicates the same gene is expressed in both tissues. Proc Natl Acad Sci USA 84: 407-411, 1987.

15. Miller WL: Minireview: regulation of steroidogenesis by electron transfer. Endocrinology 146: 2544-2550, 2005.

16. Staels B, Hum DW and Miller WL: Regulation of steroidogenesis in NCI-H295 cells: a cellular model of the human fetal adrenal. Mol Endocrinol 7: 423-433, 1993.
17. Ahlman H, Khorram-Manesh A, Jansson S, Wangberg B Nilsson O, Jacobsson CE and Lindstedt S: Cytotoxic treatment of adrenocortical carcinoma. World J Surg 25: 927-933, 2001.

18. Pushkarev VM, Tronko ND, Kostyuchenko NN and Mikosha AS Effect of o,p'-DDD and $\mathrm{Li}^{+}$on apoptotic DNA fragmentation in conventionally normal and tumour tissues of human adrenal cortex. Ukr Biokhim Zh 79: 44-49, 2007.

19. de Fraipont F, El Atifi M, Cherradi N, Le Moigne G, Defaye G, Houlgatte R, Bertherat J, Bertagna X, Plouin PF, Baudin E, Berger F, Gicquel C, Chabre O and Feige JJ: Gene expression profiling of human adrenocortical tumors using complementary deoxyribonucleic acid microarrays identifies several candidate genes as markers of malignancy. J Clin Endocrinol Metab 90: 1819-1829, 2005.

20. Dohna M, Reincke M, Mincheva A, Allolio B, Solinas-Toldo S and Lichter P: Adrenocortical carcinoma is characterized by a high frequency of chromosomal gains and high-level amplifications. Genes Chromosomes Cancer 28: 145-152, 2000.

21. Kjellman M, Kallioniemi OP, Karhu R, Hoog A, Farnebo LO, Auer G, Larsson C and Backdahl M: Genetic aberrations in adrenocortical tumors detected using comparative genomic hybridization correlate with tumor size and malignancy. Cancer Res 56: 4219-4223, 1996.

22. Stephan EA, Chung TH, Grant CS, Kim S, Von Hoff DD, Trent JM and Demeure MJ: Adrenocortical carcinoma survival rates correlated to genomic copy number variants. Mol Cancer Ther 7: 425-431, 2008.

23. Moore CC, Hum DW and Miller WL: Identification of positive and negative placenta-specific basal elements and a cyclic adenosine $3^{1}, 5^{\prime}$-monophosphate response element in the human gene for P450scc. Mol Endocrinol 6: 2045-2058, 1992.

24. Sewer MB, Nguyen VQ, Huang CJ, Tucker PW, Kagawa N and Waterman MR: Transcriptional activation of human CYP17 in H295R adrenocortical cells depends on complex formation among p54(nrb)/NonO, protein-associated splicing factor and SF-1, a complex that also participates in repression of transcription. Endocrinology 143: 1280-1290, 2002.

25. Asp V, Lindstrom V, Olsson JA, Bergstrom U and Brandt I: Cytotoxicity and decreased corticosterone production in adrenocortical Y-1 cells by 3-methylsulfonyl-DDE and structurally related molecules. Arch Toxicol 83: 389-396, 2009.

26. Shi YQ, Li HW, Wang YP, Liu CJ and Yang KD: p,p'-DDE induces apoptosis and mRNA expression of apoptosis-associated genes in testes of pubertal rats. Environ Toxicol: Mar 7, 2011 (Epub ahead of print).

27. Burow ME, Tang Y, Collins-Burow BM, Krajewski S, Reed JC, McLachlan JA and Beckman BS: Effects of environmental estrogens on tumor necrosis factor alpha-mediated apoptosis in MCF-7 cells. Carcinogenesis 20: 2057-2061, 1999.

28. Boatright KM and Salvesen GS: Mechanisms of caspase activation. Curr Opin Cell Biol 15: 725-731, 2003.

29. Lakhani SA, Masud A, Kuida K, Porter GA Jr, Booth CJ, Mehal WZ, Inayat I and Flavell RA: Caspases 3 and 7: key mediators of mitochondrial events of apoptosis. Science 311: 847-851, 2006.

30. Alenzi FQ, Lotfy M and Wyse R: Swords of cell death: caspase activation and regulation. Asian Pac J Cancer Prev 11: 271-280, 2010.

31. Fuentes-Prior P and Salvesen GS: The protein structures that shape caspase activity, specificity, activation and inhibition. Biochem J 384: 201-232, 2004.

32. Hogel H, Rantanen K, Jokilehto T, Grenman R and Jaakkola PM: Prolyl hydroxylase PHD3 enhances the hypoxic survival and G1 to $S$ transition of carcinoma cells. PLoS One 6: e27112, 2011.

33. Wilhelm S, Wagner H and Hacker G: Activation of caspase-3-like enzymes in non-apoptotic T cells. Eur J Immunol 28: 891-900, 1998.

34. Feige JJ, Cochet $\mathrm{C}$ and Chambaz EM: Type beta transforming growth factor is a potent modulator of differentiated adrenocortical cell functions. Biochem Biophys Res Commun 139: 693-700, 1986.

35. Riopel L, Branchaud CL, Goodyer CG, Adkar V and Lefebvre Y: Growth-inhibitory effect of TGF-B on human fetal adrenal cells in primary monolayer culture. J Cell Physiol 140: 233-238, 1989.

36. Ragazzon B, Cazabat L, Rizk-Rabin M, Assie G, Groussin L, Fierrard H, Perlemoine K, Martinez A and Bertherat J: Inactivation of the Carney complex gene 1 (protein kinase A regulatory subunit $1 \mathrm{~A}$ ) inhibits SMAD3 expression and TGF beta-stimulated apoptosis in adrenocortical cells. Cancer Res 69: 7278-7284, 2009. 
37. Khaidakov M, Szwedo J, Mitra S and Mehta JL: Angiostatic effects of aspirin in hypoxia-reoxygenation are linked to modulation of TGFbetal signaling. J Cardiovasc Pharmacol Ther 16: 105-110, 2011.

38. Nieminen AI, Partanen JI and Klefstrom J: c-Myc blazing a trail of death: coupling of the mitochondrial and death receptor apoptosis pathways by c-Myc. Cell Cycle 6: 2464-2472, 2007.

39. Prendergast GC: Mechanisms of apoptosis by c-Myc. Oncogene 18: 2967-2987, 1999.

40. Gartel AL and Tyner AL: The role of the cyclin-dependent kinase inhibitor p21 in apoptosis. Mol Cancer Ther 1: 639-649, 2002.

41. Shin H, Lee YS and Lee YC: Sodium butyrate-induced DAPK-mediated apoptosis in human gastric cancer cells. Oncol Rep 27: 1111-1115, 2012.

42. Suzuki A, Kawano H, Hayashida M, Hayasaki Y, Tsutomi Y and Akahane K: Procaspase 3/p21 complex formation to resist fas-mediated cell death is initiated as a result of the phosphorylation of p21 by protein kinase A. Cell Death Differ 7: 721-728, 2000
43. Tait SW and Green DR: Mitochondria and cell death: outer membrane permeabilization and beyond. Nat Rev Mol Cell Biol 11: 621-632, 2011.

44. Chen CW, Hurd C, Vorojeikina DP, Arnold SF and Notides AC: Transcriptional activation of the human estrogen receptor by DDT isomers and metabolites in yeast and MCF-7 cells. Biochem Pharmacol 53: 1161-1172, 1997.

45. Gell JS, Oh J, Rainey WE and Carr BR: Effect of estradiol on DHEAS production in the human adrenocortical cell line, H295R. J Soc Gynecol Investig 5: 144-148, 1998.

46. Vanttinen T, Liu J, Kuulasmaa T, Kivinen P and Voutilainen R: Expression of activin/inhibin signaling components in the human adrenal gland and the effects of activins and inhibins on adrenocortical steroidogenesis and apoptosis. J Endocrinol 178: 479-489, 2003 